\title{
Remisi Terhadap Koruptor dalam Perspektif Hukum Positif dan Hukum Islam
}

\author{
Ahmadi Hasan, Bahran, dan Arie Sulistyoko \\ Universitas Islam Negeri Antasari Banjarmasin, Kalimantan Selatan \\ e-mail: ahmadi.hasan@uin-antasari.ac.id
}

\begin{abstract}
This study will discuss the implementation of remission in Indonesia according to Presidential Decree No. 174/1999 on Remission, basically not apart from the basic principles of Islamic criminal law. The concept of Islamic criminal law stems from the benefit for prevention (ar-radu waz-zajru) education and teaching (al-Islab al-Tabzib). The purpose of Remission in Indonesia is as a motivator or stimulation to behave well, to reduce the negative impact of the punishment imposed.
\end{abstract}

keywords: Remission, law, criminal, islam, prisoners.

Abstrak: Penelitian ini akan membahas mengenai pelaksanaan remisi di Indonesia menurut Keputusan Presiden Republik Indonesia Nomor: 174 Tahun 1999 Tentang Remisi, pada dasarnya tidak terlepas dari prinsip-prinsip pokok hukum pidana Islam. Konsep hukum pidana Islam berpangkal pada kemaslahatan untuk pencegahan (ar-radu waz-zajru) pendidikan dan pengajaran (al-Islah al-Tahzib). Tujuan pemberian Remisi di Indonesia merupakan sebagai motivator atau stimulasi untuk berkelakuan baik, untuk mengurangi dampak negatif dari hukuman yang dijatuhkan.

Kata kunci: Remisi, bukum, pidana, islam, tahanan

\section{Latar Belakang Masalah}

Di Indonesia, masalah menjaga amanat masih perlu diperhatikan oleh banyak pihak, lebih-lebih masalah besar yaitu korupsi yang kini hampir terjadi disemua lini, baik dikalangan eksekutif maupun legislatif, baik di pusat maupun di daerah. Masalah korupsi di negeri ini sudah memasuki seluruh bidang kehidupan sosial dan pemerintahan serta sudah bersifat mengakar dalam budaya hidup, perilaku, dan cara berpikir. ${ }^{1}$

Tidak berhenti sampai disitu, korupsi pun menjadi virus yang merambah kesektor swasta sampai ketingkat RT yang jelas eksitensi korupsi dalam bangsa ini telah menimbulkan banyak kerugiaan. Ini menunjukan bahwasanya kewenangan dalam menerapkan Undang-Undang

${ }^{1}$ M. Nurul Irfan "Korupsi dalam Hukum Pidana Islam” (Jakarta: Pena Grafika,2012), h.4. 
tidak konsisten dan kurangnya ketegasan dalam menerapkan isi kandungan Undang-Undang.

Indonesia merupakan negara hukum yang dilindungi oleh UndangUndang Dasar tahun 1945 untuk mewujudkan tujuan negara yaitu good governance dan good government, maka diaturlah tatanan pemidanaan narapidana dalam satu aturan dan petunjuk pelaksana sehingga terciptanya pelayanan pemerintah yang baik. ${ }^{2}$

Segala tindakan yang menyangkut lembaga-lembaga negara yang dapat merugikan negara, maka harus ditegakkan dengan aturan-aturan yang sudah diberlakukan. Namun kenyataannya pada masa pemerintahan Presiden Susilo Bambang Yudhoyono dan wakil Presiden yaitu Budieono selama ini belum maksimal dalam menangani kasus-kasus korupsi yang masih berkembang saat ini. Seperti kasus Aulia Pohan dinyatakan terbukti bersalah dan telah merugikan negara dalam kasus aliran dana Bank Indonesia sebesar 100 Milyar Rupiah. Namun besan Presiden Bambang Susilo Yudhoyono itu ditingkat kasasi diputus hukuman hanya tiga tahun dengan denda Rp 200 Juta dari hukuman yang dijalani. Remisi yang didapatkan Aulia Pohan setelah sehari Proklamasi Indonesia, Aulia, Pohan

2 Anwar Hafidzi, "Eksistensi Advokat Sebagai Profesi Terhormat (Officium Nobile) Dalam Sistem Negara Hukum Di Indonesia," Khazanab: Jurnal Studi Islam Dan Humaniora 13, no. 1 (2015). mendapatkan hadiah pengurangan hukuman selama tiga bulan melalui remisi dan ditahun 2010 pemerintah kembali mengobral remisi bagi koruptor.

Tercatat, ada 341 koruptor yang menikmati remisi pada hari Lebaran kemaren, 11 diantaranya langsung bebas. $^{3}$ Sebelumnya, ditengah hingar bingar slogan merdeka dari korupsi pada peringatan Hari Kemerdekaan Republik Indonesia yang ke-66, pemerintah juga memberikan remisi terhadap koruptor sebanyak 419 yang menikmati remisi tersebut, bahkan 21 diantaranya langsung bebas. ${ }^{4}$ Termasuk yang menikmati remisi tahun ini adalah mantan Jaksa Urip Tri Gunawan,Urip divonis 20 tahun penjara dan denda $\mathrm{Rp}$ 500 juta. Pemerintah justru seenaknya memberi Urip remisi khusus Hari Natal dengan ketentuan maksimal remisi satu bulan pada Desember 2010. Selanjutnya, Agustus 2011, Urip mendapatkan remisi umum (hari kemerdekaan) sebesar empat bulan. Secara hukum, Urip baru menjalani tiga tahun masa pidana dan karena itu, haram mendapat remisi. ${ }^{5}$

${ }^{3}$ koruptor terima remisi selama 2010, artikel diakses pada tanggal 20 Juni 2012 jam $18.30 \quad$ pada http:/ /341 koruptorterimaremisiselama.com/201 $0 / 08 / 25 /$

${ }^{4}$ remisi untuk koruptor, artikel diakses pada tanggal 20 juni 2012 jam 20.00 pada http://remisikoruptor.com/2011/10/8/salaman tikorupi,htm

${ }^{5}$ Anwary "Perang Melawan Korupsi Di Indonesia" (Bogor, 2012), h.45. 
Hal ini merupakan suatu yang berlebihan dalam memberikan keputusan pengurangan hukuman (remisi) yang sudah diatur dalam Undang-Undang. Mereka sudah mengeruk uang negara yang menimbulkan kerugian bagi jutaan rakyat sehingga tidak pantas mendapat keistimewaan. Justru koruptor harusnya dimiskinkan dan kalau perlu diberi sanksi sosial. Memang penjara bukanlah tempat untuk balas dendam, namun penjara juga bukan tempat seorang penjahat boleh menikmati keistimewaan termasuk mendapat remisi. Menghukum seseorang koruptor secara maksimal bukan hanya pembelajaran bagi terpidana itu sendiri, melainkan juga menjadi pelajaran bagi jutaan orang di luar tembok penjara agar mengurungkan niat merampok uang negara.

Pemberantasan korupsi harus bebas dari praktik menyimpang pemberian remisi. Kita telah bersepakat bahwa korupsi adalah kejahatan luar biasa, maka harus ada upaya luar biasa pula untuk memberantasnya. Perubahan aturan mengenai remisi harus dilakukan. Jihad aparat penegak hukum juga harus diimbangi dengan memperkecil remisi bagi koruptor. Jangan samakan besaran remisi narapidana kasus korupsi dengan narapidana biasa. Penyimpangan yang telah terjadi harus ditindak tegas. Pejabat pemberi remisi yang menyimpang pun harus mendapat sanksi. ${ }^{6}$

Kalau kita menijau kembali kebijakan remisi dalam UndangUndang, maka seorang narapidana harus mempunyai persyaratan yang harus dipenuhi, yaitu intinya menaati peraturan yang ada di Lembaga Permasyarakatan, atau ia harus berusaha menjaga kelakuaan baik agar kembali memperoleh remisi selama dalam Lembaga Permasyarakatan.

\begin{tabular}{llrr}
\multicolumn{1}{c}{ Pemberian } & & remisi & bagi \\
narapidana & di & Lembaga \\
Permasyarakatan & & diatur & dalam
\end{tabular} beberapa Undang-Undang antara lain: Undang-Undang Nomor 12 Tahun 1995 Tentang Permasyarakatan menerangkan dalam Pasal 1 ayat (1) "Permasyarakatan adalab kegiatan untuk. melakukan pembinaan warga binaan permasyarakatan berdasarkan sistem, kelembagaan, dan cara pembinaan yang merupakan bagian akhir dari sistem pembinaan dalam tata peradilan". Peraturan Pemerintah Nomor. 32 Tahun 1999 tentang Syarat dan Tata Cara Pelaksanaan Hak Warga Binaan Permasyarakatan menerangkan pada Pasal 1 ayat (1) "Warga binaan pemasyarakatan, Terpidana, Narapida, Anak Didik Permasyarakatan Klien Permasyarakatan, LAPAS, BAPAS adalah warga binaan permasyarakatan, Terpidana, Narapidana, Anak Dididk Permasyarakatan, Klien Pemasyarakatan, $L A P A S, B A P A S$ sebagaimana dimaksud 
dalam Undang-Undang Nomor 12 Tahun 1995 tentang Pemasyarakatan”.

Keputusan Menteri Hukum dan Perundang-Undangan Republik Indonesia Nomor. M.09.HN.02.01 Tahun 1999 Tentang Pelaksanaan Keputusan Presiden Nomor 174 Tahun 1999 tentang Remisi menerangkan dalam pasal 1 ayat (1) yaitu "Remisi adalah pengurangan masa pidana yang diberikan kepada narapidana dan anak pidana yang telah bekelakuan baik selama menjalani pidana". Keputusan Menteri Kehakiman dan HAM Republik Indonesia Nomor. M.04HN.02.01 Tahun 2000 tentang Remisi Tambahan bagi Narapidana dan Anak Didik. Peraturan Pemerintah Nomor. 99 Tahun 2012 tentang Perubahan Kedua Atas Peraturan Pemerintah Nomor 32 Tahun 1999 tentang Syarat dan Tata Cara Pelaksanaan Hak Warga Binaan Pemasyarakatan. Dengan peraturan perundang-undangan tersebut diharapkan pemerintah benarbenar memperhatikan dalam memutuskan untuk memberikan remisi sebagaimana yang telah diatur dalam Undang-Undang, disamping juga memperhatikan tolak ukur yang menjadi sebuah pertimbangan sebelum memutuskan pemberian remisi, terlebih lagi kepada narapidana koruptor.

Dalam pemberian remisi, pihak yang berwenang tentunya mengetahui perilaku atau perbuatan para narapidana korupsi selama menjalani pidana sebagai acuan pemberian remisi yang sesuai dengan perilaku dan tindakan selama berada di Lembaga Pemasyarakatan dan tujuan pemidanaan itu sendiri. Namun kenyataannya peraturan pemerintah tentang pemberian remisi tidak berjalan dengan stabil dan kurang ditegakkannya peraturan dalam menjalankannya.

Di Indonesia, memerlukan aturan-aturan hukum yang majemuk sehingga dapat terciptanya sebuah keadilan untuk seluruh rakyat Indonesia, karena pada hakekatnya tujuan yang dicapai bangsa Indonesia itu masyarakat yang adil, makmur, tertib, dan damai untuk bisa hidup tentram berdampingan bersama masyarakat lainnya.

Sebagai umat Islam sudah selayaknya menangani permasalahan tersebut dilihat dari sudut pandang Islam. Islam merupakan agama yang datang dari Allah SWT dengan bertujuan untuk menegakkan hukum dan kemaslahatan umat yang akan memberikan rasa aman, bagi seluruh umat manusia.

Hukum Islam mempunyai beberapa keistimewaan dan beberapa keindahan yang menyebabkan hukum Islam menjadi hukum yang paling kaya, serta menjamin ketenangan dan kebahagiaan umat. Keistimewaan dan keindahan itu apabila dipraktekkan bersama-sama umat Islam, niscaya benar-benar dapat membentuk suatu 
umat yang ideal, terkumpul unsur kekuatan yang adil, keteguhan dan kehidupan yang baik . ${ }^{7}$

Tentang pengurangan/ potongan masa hukuman atau remisi di Indonesia suatu masalah tersendiri yang perlu disoroti. Terkait dengan masalah remisi ini sendiri, Islam juga mengenal adanya remisi yang di sebut dengan istilah Syafa'at. Syafa'at berasal dari kata Syafa'a yang artinya "minta Syafa'at (pengampunan) untuk si Fulan."8

Kemudian berkembang menjadi "pertolongan yang diberikan oleh seseorang kepada orang lain yang mengharapkan pertolongannya, atau usaha untuk memberikan suatu manfaat bagi orang lain dan mengurangi mudarat bagi orang lain". ${ }^{9}$

Berdasarkan latar belakang masalah yang diuraikan diatas, maka perlu dilakukan perluasan penelitian. Adapun rumusan pokok permasalahan yang akan dikaji dari penelitian ini adalah sebagai berikut :

1. Bagaimana remisi bagi koruptor di dalam peraturan perundangundangan?

${ }^{7}$ M.Hasbi Ash Shiddieqy, Falsafah Hukum Islam (Jakarta: Bulan Bintang, 1990), h.119

${ }^{8}$ Al-Munawwir, A.Warson Munawwir,

Kamus Arab-Indonesia Yogyakarta: Unit Pengadaan buku-buku Ilmiah Keagamaan Ponpes al_Munawwir, 1984)., h.780.

${ }^{9}$ Abdul Azis Dahlan, et.al., (eds), Eksiklopedi Hukum Islam (Jakarta: Icthiar Baru Van Hoeve, 1996). Jilid 5 h.325
2. Bagaiamana remisi bagi koruptor dalam pandangan hukum pidana Islam?

\section{Pengertian Remisi Dalam Perundang Undangan Dan Hukum Pidana Islam}

Remisi sangat berkaitan dengan Lembaga Pemasyarakatan, terutama dengan para penghuninya Narapidana. Adapun beberapa pengertian Remisi yang mempunyai maksud dan tujuan tertentu, Remisi berasal dari kata remissio yang berasal dari bahasa latin yang berarti potongan/pengurangan hukuman. Sedangkan menurut istilah, Remisi adalah pembebasan hukuman untuk seluruhnya atau sebagian dari hukuman seumur hidup menjadi hukumana terbatas. ${ }^{10}$

Sedangkan menurut ketentuan Pasal 1 Keputusan Presiden Republik Indonesia Nomor 174 Tahun 1999, tidak memberikan pengertian Remisi, disana hanya dikatakan: "Setiap Narapidana dan Anak Pidana yang menjalani Pidana kurungan dapat diberikan Remisi apabila yang bersangkutan berkelakuan baik selama menjalani pidana."

Maksud dari kelakuan baik disini ialah narapidana yang bersangkutan selalu menaati peraturan yang berlaku dan tidak dikenakan

${ }^{10}$ Andi Hamzah, "Kamus Hukum", loc. 
tindakan disiplin yang dicatat dalam buku register $\mathrm{F}$ selama kurun waktu yang diperhitungkan untuk pemberian Remisi.

Dalam hal ini dapat dilihat sedikit keringanan yang diberikan oleh Negara, yaitu dengan diperbolehkannya untuk mendapatkan Remisi setelah memenuhi ketentuan-ketentuan yang berlaku. Hal ini berarti bahwa negara benar-benar memberi perhatian yang serius kepada orang-orang yang telah gagal mengimplementasikam makna dari pembinaan yang telah diberikan sebelumnya. Secara jelas mengenai besarnya Remisi yang diberikan kepada narapidana dari Anak pidana berdasarkan ketentuan Pasal 2 dan 3 Keputusam Presiden Republik Indonesia Nomor 174 Tahun 1999 tentang Remisi, dikenal jenisjenis/bentuk Remisi yaitu:

1. Remisi umum, adalah Remisi yang diberikan pada Hari Peringatan Proklamasi Kemerdekaan RI tanggal 17 Agustus.

2. Remisi khusus, adalah pengurangan masa pidana yang diberikan kepada Narapidana dan Anak Pidana pada Hari Besar Keagamaan yang dianut oleh yang bersangkutan dan dilaksanakan sebanyak-banyaknya 1 (satu) kali dalam setahun bagi masing-masing agama.. Berdasarkan Keputusan Menteri Hukum dan Perundangundangan RI Nomor M.09.HN.02.01 Tahun 1999 tentang Pelaksanaan Keputusan Presiden Nomor 174 Tahun 1999, pasal 3 ayat (2), bahwa pemberian Remisi khusus didasarkan pada:

a. Setiap Hari Raya bagi Narapidana dan Anak Pidana yang beragama Islam

b. Setiap Hari Raya Natal bagi Narapidana dan Anak Pidana yang beragama Kristen/Khatolik.

c. Setiap Hari Raya Nyepi bagi Narapidana dan Anak Pidana yang beragama Hindu.

d. Setiap Hari Raya Waisak bagi Narapidana dan Anak Pidana yang beragama Budha.

3. Remisi Tambahan adalah pengurangan masa pidana yang diberikan kepada Narapidana dan Anak Pidana yang berbuat jasa kepada Negara, melakukan perbuatan yang bermanfaat bagi Negara atau kemanusiaan atau melakukan perbuatan yang membantu kegiatan Lembaga Pemasyarakatn.

Terkait dengan masalah pengurangan masa hukuman (Remisi) pemerintah di Indonesia, syariat Islam terdapat suatu aturan yang cukup penting dalam hal pengurangan masa hukuman (Remisi). Islam mengenal dengan adanya pengurangan masa hukuman (Remisi) yaitu dikenal dengan pengampunan atau dengan istilah Syafa'at. Syafa'at berasal dari kata Syafa'a yang artinya "minta Syafa'at 
pengampunan untuk si Fulan."11 Kemudian arti tersebut berkembang menjadi pertolongan yang diberikan oleh seseorang kepada orang lain yang mengaharapkan pertolongannya, usaha dalam memberikan suatu manfaat bagi orang lain atau mengurangi mudarat bagi orang lain. ${ }^{12}$

Dalam Islam sangat dianjurkan sekali memberikan Syafa'at (pengampunan) sesama orang lain, selama pemberian Syafa'at tersebut akan memberikan kemaslahatan dan menghindari dari kemudharatan. Karena Rasulullah sendiri sering menganjurkan untuk memberikan Syafa'at atau pertolongan kepada orang lain yang membtuhkannya. Hal tersebut sebagaimana yang telah disabdakan oleh Nabi SAW:

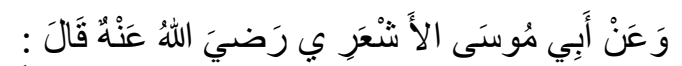

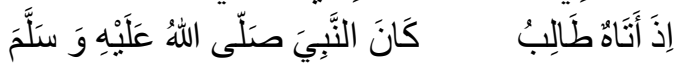

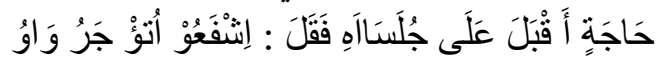

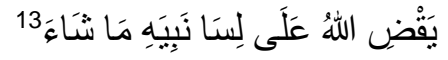

"Dan dari Abu Musa Al-Asy'ari Radhiyallahu Anbui a berkata, "Nabi Shallallabu Alaibi wa sallam jikea didatangkan oleh orang yang meminta hajat, belian menghadap kepada orang-orang yang

${ }^{11}$ Al-Munawwir A.Warson Munawwir, Kamus Arab-Indonesiaan, loc. Cit.

${ }^{12}$ Abdul Azis Dahlan, et.al., (eds), Eksiklopedi Hukum Islam (Jakarta: Icthiar Baru Van Hoeve, 1996). Jilid 5.h.325.

${ }^{13}$ Imam abu Zakariya Yahya bin Syaraf An- Nawawi, Riadhus Shalibin Min Kalaami Syaidil Mursalyin ( Damaskus: Darul Khair, 1420 H), h. 82 duduk, dihadapannya, 'Berilah syafa'at, maka kalian akan diberi pahala, dan Allah akan memenubi atas lisan nabinya apa yang ia sukai". ${ }^{14}$

Islam sendiri telah memberikan batasan-batasan berkaitan dengan pemberian Syafa'at. Batasan-batasan tersebut berlaku suatu tindakan pidana yang diancam dengan hukumanhukuman tertentu sebagaimana yang telah ditetapkan oleh peraturan kepidanaan syariat Islam. Ketentuanketentuan hukuman dalam pidana Islam adalah pidana had, qisa/diyat dan ta'zir, ketentuan tersebut merupakan batasan diperbolehkan atau tidaknya memberi Syafa'at, karena hal tersebut merupakan hak Allah dan juga manusia di dunia dan diakhirat. Sehingga batasan-batasan ini menjadikan seseorang lebih berhati-hati dalam memberikan Syafa'at kepada orang lain, khususnya terhadap tindak pidana, karena kesalahan dalam memberikan Syafa'at justru menimbulkan hal-hal yang negatif (kemudharatan).

\section{Tujuan Pemberian Remisi}

Sedangkan maksud dan tujuan dalam memberikan Remisi menurut Keputusan Presiden Republik Indonesia Nomor 174 Tahun 1999, yaitu :

1) Sebagai motivator dan stimulasi serta dijadikan alat untuk

${ }^{14} \mathrm{AlHafidh}$ Masrap Suhaemi BA, Tarjamah Riadhus Shalibin ( Surabaya: Mahkota, 1986), h. 339 
mengingatkan narapidana dan Anak pidana untuk berkelakuan baik selama berada di Lembaga Permasyarakatan.

2) Sebagai upaya untuk mengurangi dampak negatif dan subkultural tempat pelaksanaan pidana, disparitas pidana akibat perampasan kemerdekaan. Bahwa secara psikologi, pemberian Remisi ini mempunyai pengaruh dalam menekan tingkat frustasi (terutama bagi narapidana residivis). Sehingga dapat mereduksi atau meminimalisasikan gangguan keamanan dan ketertiban di LP/Rutan, yang berupa pelarian dan kerusuhan lainnya.

3) Bahwa Remisi khusus yang diberikan pada saat hari besar keagamaan, diharapkan sebagai pemacu warga binaan pemasyarakatan untuk penyadaran diri sesuai dengan tuntutan Agama dalam kehidupan kesehariannya.

Dalam pelaksanaan hak-hak narapidana, pemerintah memberikan kesempatan kepada narapidana yang dijatuhkan hukuman seumur hidup untuk memperbaiki diri dan mempunyai harapan untuk kembali ke tengah-tengah masyarakat melalui proses pemasyarakatan. Selain hal-hal ini, maksud tujuan dengan adanya pemberian Remisi adalah sebagai salah satu kebijakan hukum pidana dalam rangka mewujudkan tujuan sistem pemasyarakatan diharapkan sesuai Standard Minimum Rules. ${ }^{15}$

Maksud dan tujuan dari pemberian Remisi di Indonesia pada dasarnya tidak terlepas dari prinsipprinsip pokok hukum pidana Islam. Islam sebagai Agama yang terakhir yang diwahyukan oleh Nabi Muhammad SAW telah dijamin kesempurnaannya. Syariat Islam itu sendiri perlu ditegakkan di bumi Allah, jadi perlu ditanamkan kepada semua masyarakat tentang Syariat dan hukumhukumnya. Hukum itu ditetapkan untuk memperbaiki individu menjaga masyarakat tertib sosial. Hukuman itu harus mempunyai dasar, baik AlQur'an, dan Al-Sunnah sehingga terjamin kebenarannya. Adanya hukuman itu dapat menjamin ketentraman dan keberuntungan bersama, Islam membagi hukuman duniawi dengan dua macam:

1. Hukuman yang dikuasakan kepada hakim, menurut yang dipandangnya maslahat, sesuai dengan masa tempat dan keadaan.

2. Hukuman tertulis yang tidak boleh dilampaui dan dikurangkan dari batasnya. Hal demikian bersifat kejahatan dalam anggapan

15Zainal Arifin"Tinjauan Hukum Islam Terhadap Pemberian Remisi Pada Narapidana". Skripsi diakses pada tanggal 21 November 2012 jam 11.30, h. 62 . 
seluruh manusia disetiap masa dan tempat. ${ }^{16}$

Tujuan hukum Islam itu sendiri adalah untuk memelihara dan menciptakan kemaslahatan manusia dan menjaga mereka dari hal-hal yang mafsadah, karena Islam itu sebagai rahmat-anlil'alamin, untuk memberi petunjuk dan pelajaran kepada manusia. ${ }^{17}$ Selain itu hukuman harus bersifat pribadi, artinya hanya dijatuhkan kepada yang melakukan kejahatan saja. Hal ini sesuai dengan prinsip bahwa: "seseorang tidak menanggung dosanya orang lain”. Hukuman itu pun harus berlaku untuk semua orang, karena semua manusia sama dihadapan hukum.

Tujuan terakhir dari hukuman syari'at itu sendiri ialah pencegahan (arrad-u waz-zajru) dan pengajaran serta mendidik jiwa (al-islabwat-tabdrib). Pencegahan atas suatu pidana / Jarimah berarti berusaha menahan pelaku agar tidak mengulangi perbuatan Jarimahnya atau agar tidak terus-menerus melakukan perbuatannya, disamping pencegahan terhadap orang lain agar tidak mengulangi Jarimah. Sebab, ia sudah mengetahui hukuman yang akan mereka terima dan jika ia berbuat suatu Jarimah yang sama seperti yang dialami oleh pelaku yang berbuat Jarimah.

\footnotetext{
${ }^{16}$ Syekh Mahmud Syaltut, "Aqidah dan Syariah Islam II", alih bahasa facruddin Hs(Jakarta: PT. Bima Aksara, 1985), h.28.

${ }^{17}$ Ahmad Dzajuli, Fiqih Jinayah "Upaya Menanggulangi Kejahatan dalam Islam”. (Jakarta: Raja Grafindo persada, 1997), h.25
}

Dengan demikian, maka pencegahan mempunyai kegunaan yang rangkap. ${ }^{18}$

\section{Aturan-aturan tentang Pemberian Remisi}

Adapun Remisi dalam hukum pidana Islam masuk dalam suatu pembagian Jarimah. Pembagian Jarimah yang paling penting adalah pembagian yang ditinjau dari segi aspek hukumanya. Jarimah yang ditinjau dari segi aspeknya, maka dibagi menjadi tiga bagian yaitu Jarimah Hudud, Jarimah Qisas, Jarimah Ta'zir. ${ }^{19}$

\section{Jarimah Hudud}

Jarimah budud merupakan bentuk jamak dari kata hadd dalam bahasa Arab berarti "membatasi/memberi, batasan, rintangan". Dalam ilmu fiqh, Hudud atau Hadialah hukuman atas perbuatan pidana tertentu (Jarimah budud) yang jenis dan bentuk hukumanya telah ditentukan Syari' (pembuat syariat/Allah SW'T), tidak bisa ditambah atau dikurangi. Hukuman ini merupakan hak Allah dalam pengertian tidak bisa dihapuskan baik oleh perseorangan (orang yang menjadi korban atau keluarganya) maupun oleh

\footnotetext{
${ }^{18}$ Ahmad Hanafi, Asas-Asas Hukum Pidana Islam (Jakarta: Bulan Bintang, 1967), h. 255.

${ }^{19}$ Ahmad Wardi Muslich, Hukum Pidana Islam (Jakarta: Sinar Grafika, 2005), h. x.
} 
masyarakat yang diwakili lembaga Negara. ${ }^{20}$

Jarimah Hudud dalam hukumanya telah ditentukan dengan ketentuan hukum yang terdapat dalam Al-Quran dan As-Sunnah. Jarimah budud dalam hukumannya telah ditentukan dengan ketentuan hukum yang terdapat dalam Al-Qur'an dan AsSunnah. Adapun ciri khas jarimah budud adalah sebagai berikut :

a. Hukumannya tertentu dan terbatas, dalam arti bahwa hukuman tersebut telah ditentukan oleh syara' dan tidak ada batasan minimal dan maksimal.

b. Hukuman tersebut merupakan hak Allah semata-mata, atau kalau ada hak manusia di samping hak Allah maka hak Allah yang lebih dominan.

Untuk pembagian Jarimah Hudud ada tujuh macam, yaitu Jarimab Zina, Jarimah Qadzab, Jarimah Syurb alKhamr, Jarimah Pencurian, Jarimah Hirabah, Jarimah Riddah, Jarimah pemberontak Jarimah Hudud ini hukumanya telah ditentukan dengan ketentuan-ketentuan hukum yang terdapat dalam Al-Quran dan AsSunnah. Namun dalam Jarimah ini apabila pelaku Jarimah telah taubat dan menyesali perbuatannya, maka

${ }^{20}$ Nina M. Armanndo, et al. Enksikelopedi Islam (Jakarta: Ichtiar Baru Van Hoeve, 2005). Jilid 3, h.43 hapuslah hukumnya meskipun itu telah melakukan Jarimah yang selesai. Hal ini sesuai dengan Firman Allah SW'T pada Q.S Al-Maidah ayat 34:

"Kecuali orang-orang yang taubat (di antara mereka) sebelum kamu dapat menguasai (menangkap) mereka Maka ketabuilah bahwasanya Allab Maha Pengampun lagi Maha Penyayang.

Adapun Hadits sabda Nabi SAW yaitu:

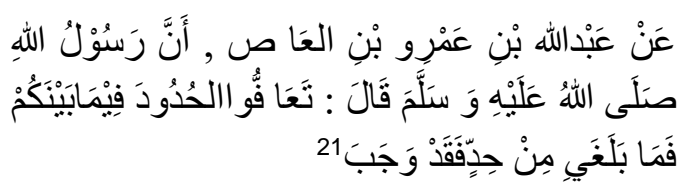

"Dari Abdullah bin Umar bin Al Ash, Bahwa Rasulullab SAW bersabda, "Berilah maaf dalam kasus Hudud yang terjadi diantara kalian (karena) kasus yang telah sampai kepadaku, maka itu wajib untuk dilaksanakan".

Kebolehan memberi Syafa'at pada keadaan ini terbatas pada pelaku pidana tersebut, apabila kasusnya belum diajukan kepada penguasa dan pelaku menyesali perbuatannya atau dengan kata lain berataubat. Dan jika perkaranya sudah sampai ketangan penguasa/hakim maka wajib dilaksanakan hukuman Hadd, dan hal ini merupakan ketentuan hukum Allah yang harus dilaksanakan serta

${ }^{21} \mathrm{Abu}$ daud, Sunan Abi Daud, Kitab Hudud, Bab Afwi an al-Hududi Malam Tablughi as-Sultana (Beirut : Mua'sasah Rayyan, 1998 M/1319H) V : 72-73, Hadits Nomor 4376. Hadits dari Abdullah bin Amr bin Ash. 
merupakan balasan setimpal dari hukuman Allah SWT.

Berkaitan dengan masalah pengampunan (Syafa'at) para fuqaha telah sepakat bahwa hakim atau penguasa diharamkan memberi Syafa'at, baik itu pengurangan hukuman maupun pembebasan hukuman sama sekali bila perkaranya sudah sampai ketangan hakim atau penguasa penegak hukum. Karena tindakan memberi Syafa'at sesudah perkaranya sampai ketangan hakim berarti telah menggagalkan untuk mewujudkan perbaikan, dan mentolerir pelanggaran dan melepaskan tertuduh dari akibat kejahatan yang telah diperbuatnya.Sebab pemberian Syafa'at pada kondisi tersebut berarti menghalangi hakim untuk melakukan kewajibannya dan membuka peluang untuk tidak tegaknya supremasi hukum.

Dari uraian di atas tentang
Syafa'at Jarimah Hudud terdapat
ketentuan-ketentuan yang berkaitan
dengan pemberian Syafa'at dalam
Jarimah Hudud, adapun ketentuan
tersebut:

a) Pemberian

pengampunan (Syafa'at) baik berupa pembebasan hukuman ataupun pengurangan hukuman kepada pelaku tindak pidana yang diancam dengan hukuman Hadd sesudah perkaranya diajukan kepada hakim tidak diperbolehkan adanya pemberian ampunan/Syafa'at.

b) Pemberian ampunan kepada tindak pidana yang diancam dengan hukuman Hadd sebelum perkaranya diajukan pada hakim atau penegak hukum diperbolehkan adanya pengampunan, dan pelaku menyesali perbuatannya (taubat) selama Syafa'at tersebut tidak membahayakan atau mengganggu ketentraman umum.

2. Jarimah Qisas

Jarimah qisas dan diyat adalah jarimah yang diancam dengan hukuman qishash maupun diyat. Baik qisas maupun diyat kedua-duanya adalah hukuman yang sudah ditentukan oleh syara'. Pengertian qisas, sebagaimana di kemukan oleh Muhammad Abu Zahra yang dinukilkan oleh Ahmad Wardi Muslich adalah "persamaan dan keseimbangan antara jarimah dan hukuman". ${ }^{22}$ Pada Q.S. Al-Baqarah ayat 178

"Hai orang-orang yang beriman, diwajibkan atas kamu qishaash berkenaan dengan orangorang yang dibunub; orang merdeka dengan orang merdeka, hamba dengan hamba, dan wanita dengan wanita. Maka Barangsiapa yang mendapat suatu pema'afan dari saudaranya, bendaklah (yang mema'afkan) mengikuti dengan cara yang baik, dan

${ }^{22} \mathrm{Ahmad}$ Wardi Muslich, Hukum Pidana Islam, ( Jakarta: Sinar Grafika, 2005), h.xi 
Jurnal Syariah: Jurnal Ilmu Hukum dan Pemikiran

Vol 17, Nomor 2 Desember 2017
Remisi terhadap Koruptor dalam ..223-250

Abmadi Hasan, Babran \& Arie Sulistyoko hendaklah (yang diberi ma'af) membayar (diat) kepada yang memberi ma'af dengan cara yang baik (pula). yang demikian itu adalab suatu keringanan dari Tuban kamu dan suatu rahmat. Barangsiapa yang melampani batas sesudah itu, Maka baginya siksa yang sangat pedib".

Ayat diatas menurut Muhammad Bin Alwi al Maliki merupakan kemurahan bagi umat Muhammad yaitu mendapatkan ampunan tidak di qisas, tetapi harus membayar diyat. Lain dengan ketentuan atas Bani Israil telah ditentukan hukuman pembalasan atas mereka qis\{as\{meskipun pembunuhan yang mereka lakukan itu sengaja. ${ }^{23}$ Ketentuan atas bani Israil tersebut terkandung dalam firman Allah pada Q.S Al-Maidah ayat 45

"Dan Kami telah tetapkan terhadap mereka di dalamnya (At Taurat) babwasanya jiwa (dibalas) dengan jiwa, mata dengan mata, bidung dengan hidung, telinga dengan telinga, gigi dengan gigi, dan luka luka (pun) ada kisasnya. Barangsiapa yang melepaskan (hak qis\{as\{) nya, Maka melepaskan hak itu (menjadi) penebus dosa baginya. Barangsiapa tidak memutuskan perkara menurut apa yang diturunkan Allah, Maka mereka itu adalah orang-orang yang zalim".

Kewenangan memberikan pengampunan dalam jarimah qisas ini

23 Muhammad Bin Alwi Al Maliki, keutamaan Umat Muhammad, alih bahasa Bughawi (Jakarta: Bintang Terang, 2001) h.3. berada pada pihak korban. Jika korban dan wali korban bersedia memaafkan maka hukum qisas batal dan dapat digantikan dengan diyat, tetapi sebaliknya jika pihak korban atau wali korban menghendaki hukuman qisas maka hukuman tersebut harus dilaksanakan. Kekuasaan hakim dalam memberikan maaf ini tergantung pada persetujuan pihak wali korban. Hakim dalam hal ini hanya sebagai pelaksana. Berkenaan dengan orang yang berhak menuntut qisas/diyat atau memberikan pengampunan, Imam Malik berpendapat bahwa mereka yang berhak menuntut qisas/diyat ataupun memberikan pengampunan adalah kelompok ashabah bi nafsi. ${ }^{24}$

Hukuman qisas itu dapat terhapus karena dengan ha-hal sebagai berikut:

1) Hilangnya tempat untuk di qisas;

2) Pemaafan;

3) Perdamaian;

4) Diwariskan hak qisas.

Pemberian maaf ini merupakan hal yang paling mulia. Islam, disamping mensyaratkan hukuman qisas, secara serentak juga menggemarkan pemeluknya untuk suka memaafkan. Dan pemberian maaf (pengampunan) itu berlangsung sampai vonis qisas dijatuhkan secara adil. Pemberian maaf

${ }^{24}$ Ashabah bi nafsib adalah orang yang paling dekat dengan korban itulah yang paling berhak untuk penjatuhan hukuman itu. Lihat Dzajuli, Figh Jinayah. ..., h.149 
(pengampunan) itu lebih utama daripada menuntutnya. Sebagaimana terdapat dalam hadist:

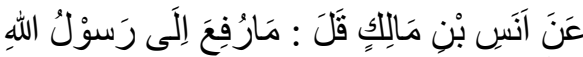

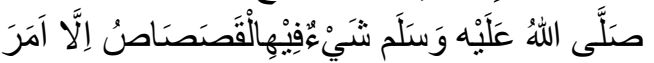
25 فِيْْهِ بِالعَفْفِ

"Sepengetahuan saya setiap ada perkara qisas dilaporkan kepada Rasulullah Saw maka beliau selalu memerintabkan agar dimaafkan"

Yang dimaksud pemaafan menurut Imam Syafi'i dan Imam Ahmad adalah memaafkan qisas atau diyat tanpa imbalan apa-apa. Sedangkan menurut Imam Malik dan Imam Abu Hanifah pemaafan terhadap diyat itu bisa dilaksanakan bila ada kerelaan pelaku/terhukum. Jadi menurut kedua ulama terakhir ini pemaafan adalah qisas tanpa imbalan apa-apa. Adapun memaafkan diyat itu, bukan pemaafan melainkan perdamaian. Orang yang berhak memaafkan qisas adalah orang yang berhak menuntutnya. ${ }^{26}$

Tidak ada perbedaan pendapat dikalangan ulama tentang perdamaian dan hapusnya hukuman qisas karenanya, dan melalui perdamian pihak pembunuh bisa membayar tanggungan yang lebih kecil, sama atau lebih besar daripada diyat. Orang yang berhak mengadakan perdamian adalah

${ }^{25}$ Ibnu Majah, Sunan ibnu Majah, Bab alAfwi bi al-Qishasha, (Beirut: Dar al-Fakr, t,t) h:898. Hadits dari Anas bin Malik

${ }^{26}$ Ahmad Djazuli, Fiqib Jinayah "Upaya Menanggulangi Kejahatan dalam Islam”.(Jakarta: Raja Grafindo persada, 1997), h. 151-152. orang yang berhak atas qisas dan pemaafan. Qisas juga dapat dihapus karena diwariskan kepada keluarga korban.

\section{Jarimah Ta'zir}

Jarimah Ta'zir menurut bahasa ta'zir berasal dari kata 'azzara yang berarti mencegah dan menolak. ${ }^{27}$ menurut Abd Al-Aziz 'Amir yang dinukil Ahmad Wardi Muslich ta'zir juga diartikan dengan $A r$-Raddu wal Man'u (menolak dan mencegah). ${ }^{28}$ Karena ia dapat mencegah pelaku agar tidak mengulangi perbuatannya. Ta'z̧ir juga dapat diartikan mendidik dan memperbaiki agar ia menyadari perbuatan jarimahnya kemudian meninggalkan dan menghentikannya. ${ }^{29}$

Menurut istilah, didefinisikan oleh alMawardi ta'zir adalah sebagai berikut:

'Ta'zir adalab bukuman yang bersifat pendidik atas perbuatan dosa (maksiat) yang bukumannya belum ditetapkan oleh syara."

Sementara menurut Wahbah Zuhaili memberikan definisi ta>'z̧ir sebagai berikut:

'Ta'ziir menurut syara' adalah bukuman yang ditetapkan atas perbuatan maksiat atau

${ }^{27}$ Ibrahim Unais, al-Mu'jam al-Wasith, (Mesir: Dar at-Turas al-Arabi, t.t), h.598. ${ }^{28}$ Ahmad Wardi Muslich, Hukum Pidana Islam (Jakarta: Sinar Grafika, 2005), h.xii.

${ }^{29}$ Makhrus Munajat, Hukum Pidana Islam di Indonesia (Yogyakarta: Teras, 2009), h.177. ${ }^{30}$ Ibid, h.178 
Jurnal Syariah: Jurnal Ilmu Hukum dan Pemikiran

Vol 17, Nomor 2 Desember 2017
Remisi terhadap Koruptor dalam ..223-250

Abmadi Hasan, Babran \& Arie Sulistyoko jinayah yang tidak dikenakan bukuman had dan tidak pula kifarat. ${ }^{\text {’31 }}$

Dari definisi-definisi yang dikemukakan diatas, jelaslah bahwa ta'zir adalah suatu istilah untuk hukuman atas jarimah-jarimab yang hukumanya belum ditetapkan oleh syara'. Di kalangan fuqaha, jarimabjarimah yang hukumanya belum ditetapkan oleh syara' dinamakan dengan jarimah ta'zir.Jadi, istilah ta'zir bisa digunakan untuk hukuman dan bisa juga untuk jarimah.

Ta'zir tidak disebutkan secara tegas dalam Al-Quran dan hadits-hadits Rasulullah SAW. Maka, untuk menentukan jenis dan ukuranya menjadi wewenang hakim atau penguasa setempat. Dalam memutuskan jenis dan ukuran sanks ta'żir harus tetap memperhatikan isyarat-isyarat dan petunjuk nash keagamaan secara teliti dan mendalam, karena hal ini menyangkut kepentingan dan kemaslahatan umum atau masyarakat dalam sebuah negara.

Faktor yang menyebabkan hapusnya hukuman ta'zir ini banyak sekali dan berbeda-beda sesuai dengan jenis hukumanya, diantaranya adalah meninggalnya si pelaku, pemafaan, taubatnya dari pelaku, dan kadaluwarsa ${ }^{32}$. Hukuman ta'zirboleh dan harus diterapkan sesuai

\footnotetext{
${ }^{31}$ Ibid.

${ }^{32}$ Ahmad Dzajuli, Fiqib Jinayah "Upaya Menanggulangi Kejahatan dalam Islam”. (Jakarta: Raja Grafindo persada, 1997, h.233.
}

dengan tuntutan kemaslahatan, dalam kaitan ini ada sebuah kaidah yang berbunyi :

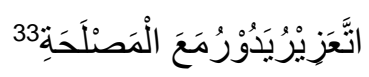

"Ta'zir itu sangat tergantung kepada tuntutan kemaslahatan"

Wahbah al-Zuhaili juga mengemukakan bahwa pembagian hukuman ta'zir terdapat dua macam, yaitu pertama, ta'zir yang diberlakukan berkaitan terhadap pelanggaran hak Allah, dan kedua, ta'sir yang diberlakukan dengan perlanggaran terhadap hak manusia sebagai individu, bukan sebagai jamaah kaum muslim. ${ }^{34}$

Hukuman ta'zir jumlahnya sangat banyak dan tidak terbatas sehingga dalam hal ini seorang hakim atau para pihak yang terlibat dalam penyusunan Undang-Undang disebuah negara harus benar-benar jeli dalam berbagai perundang-undangan merupakan bentuk konkret dari hukuman ta'zir.Untuk kasus di Indonesia, masalah korupsi dari sisi aturan sesungguhnya telah lebih dari cukup.Bahkan menurut Andi Hamzah, Undang-Undang korupsi di Indonesia bersifat terlalu luas sesuai dengan jumlah korupsi yang juga sangat banyak. $^{35}$

${ }^{33}$ Ahmad Dzajuli, Fiqih Jinayah..., loc. cit. ${ }^{34}$ Nurul Irfan, Korupsi dalam Hukum Pidana Islam (Jakarta: Pena Grafika, 2012), Cet. 1, h.150

${ }^{35}$ Op. cit. h. 152 
Tindakan mengambil harta, uang atau hak pihak lain ini bisa disebut dengan mencuri. Namun, mengingat mencuri itu termasuk wilayah jarimah budud bersama enam jenis jarimah lain, Jarimah Zina, Jarimah Qadzab, Jarimah Syurb al-Khamr, Jarimah Pencurian, Jarimah birabah, Jarimah Riddah, Jarimah pemberontak Jarimah Hudud ini hukumanya telah ditentukan dengan ketentuan-ketentuan hukum yang terdapat dalam Al-Quran dan AsSunnah. Maka sanksi hukum tindak pidana korupsi tidak bisa disamakan dengan sanksi pidana pencurian atau perampokan.

Pembahasan tentang sanksi yang diterapkan dalam jarimah ta'zir ada berbagai macam ragam. Oleh maka dari itu maksud utama dari sanksi ta'zir adalah sebagai Preventif dan Represif serta Kuratif dan Edukatif.

1) Preventif adalah ta'zir yang harus memberikan dampak positif bagi orang lain, sehigga orang lain tidak akan meniru perbuatannya.

2) Represif adalah ta'zir yang harus memberikan dampak positif bagi si terhukum, sehingga pelaku tersebut tidak lagi mengulangi perbuatannya agar tidak dijatuhi hukuman ta'zir.

3) Kuratif adalah ta'żir itu harus mampu membawa perbaikan sikap prilaku di kemudian hari.

4) Edukatif adalah bahwa sanksi harus mampu menumbuhkan

hasrat terhukum untuk mengubah pola hidupnya sehingga ia akan menjauhi perbuatan maksiatannya bukan karena takut dengan hukuman melainkan semata-mata karena tidak senang terhadap kejahatan. ${ }^{36}$

Sanksi ta'z̧ir itu ada berbagai macam ragam, diantaranya adalah sebagai berikut:

a) Sanski ta'zir yang mengenai badan. Hukuman yang terpenting dalam hal ini adalah hukuman mati dan jilid.

b) Sanksi ta'zir yang berkaitan dengan kemerdekaan seseorang, sanksi yang terpenting dalam gal ini adalah penjara dengan berbagai macamnya dan persaingan.

c) Sanksi ta'zir yang berkaitan dengan harta, hukuman ini diterapkan dengan adanya denda, penyitaan/perampasan dan pengahancuran barang.

d) Sanski-sanksi lainnya yang ditentukan oleh Ulil Amri demi kemaslahatan.

Hukuman ta'zir yang lebih terpenting yaitu sanski ta'zir yang berkaitan dengan kemerdekaan seseorang, sanski yang diterapkan

${ }^{36}$ Ahtmd Dzajuli, Figh Jinayah....,Op. cit,. h. $186-187$ 
dengan hukuman penjara. Penjara (alHabsu) menurut bahasa menahan. Menurut pendapat Ibn Qayyim itu penjara (al-Habsu) adalah menahan seseorang untuk tidak melakukan perbuatan hukum, baik itu hukuman rumah, masjid maupun ditempat lain. ${ }^{37} \mathrm{Hal}$ ini sesuai dengan firman Allah SWT pada Q.S An-Nissa ayat 15:

"dan (terbadap) Para wanita yang mengerjakan perbuatan keji, hendaklah ada empat orang saksi diantara kamu (yang menyaksikannya). kemudian apabila mereka telah memberi persaksian, Maka kurunglah mereka (wanita-wanita itu) dalam rumah sampai mereka menemui ajalnya, atau sampai Allah memberi jalan lain kepadanya".

Hukuman penjara menurut para ulama itu terbagi menjadi dua yaitu: penjara yang dibatasi waktunya dan penjara yang tidak dibatasi waktunya. Dalam kenyataannya para ulama berbeda pendapat tentang batasanbatasan yang dipakai dalam pemenjaraan, maka demi kemaslahatan dan kepastian hukum Ulil Amri perlu menentukan batasan-batasan tertinggi dan terendah bagi sanksi ta'zir yang berupa pemenjaraan. Penjara yang tidak dibatasi waktunya bisa berupa pemenjaraan seumur hidup, bisa juga dibatasi sampai terhukum bertaubat. Sedangkan hukuman penjara yang dibatasi sampai terhukum bertubat sesungguhnya mengandung

${ }^{37}$ Ahmad Dzajuli, Fiqib Jinayah "Upaya Menanggulangi Kejahatan dalam Islam”, Loc. Cit. pendidikan, mirip dengan Lembaga Pemasyarakatan sekarang, yang menerapkan adanya Remisi bagi terhukum yang terbukti ada tandatanda telah bertaubat. ${ }^{38} \mathrm{Hal}$ ini sesuai dengan salah satu tujuan pemidanaan dalam hukum Islam, yaitu pemidanaan mengandung unsur pencegahan (ar-radu waz-zajru) pendidikan dan pengajaran (al-Islah al-Tahzib). ${ }^{39}$

Taubat adalah sadar dan menyesal akan dosa (perbuat yang salah atau jahat) dan akan berniat akan memperbaiki tingkah laku dan perbuatan. Para ulama sepakat menyatakan bahwa taubat dari setiap dosa yang pernah dilakukannya termasuk dosa karena korupsi hukumnya wajib. Taubat itu bisa menghapuskan sanksi ta'zir apabila jarimah yang dilakukan oleh si pelaku adalah jarimah yang berhubungan dengan hak Allah/hak jamaah. Jumhur ulama sepakat bahwa taubat itu dapat menghapuskan hukuman bila jarimanya adalah jarimah $b>i r a^{\wedge} b a h$, sesuai dengan firman Allah SWT pada Al-Ma'iddah ayat 34 :

"Kecuali orang-orang yang taubat (di antara mereka) sebelum kamu dapat menguasai (menangkap) mereka; Maka ketabuilah bahwasanya Allah Maha Pengampun lagi Maha Penyayang".

${ }^{38}$ Ahmad Dzajuli, Fiqib Jinayah "Upaya Menanggulangi Kejahatan dalam Islam”. (Jakarta: Raja Grafindo persada, 1997), h.203-204.

${ }^{39}$ Ahmad Hanafi, Asas-Asas Hukum Pidana Islam, loc. Cit. 
Para fuqaha pun berbeda pendapat untuk masalah jarimah termasuk masalah jarimah ta'zir menurut sebagian fuqaha dari mazhab Syafi'i dan mazhab Hambali mengatakan taubatnya pelaku jarimah sebelum ditangkap dapat menghapuskan hukuman. Alasannya yang dikemukakan dalam al-Qur'an menyatakan taubat itu dapat diterima dan menghapus hukuman birabah, sedangkan hirabah itu adalah jarimah yang paling berbahaya, kalau taubat itu dapat mengahapuskan hukuman jarimah yang paling berbahaya, maka lebih-lebih dalam jarimah lain yang bahayanya lebih kecil.

Adapun pendapat yang menguatkan hal tersebut yakni adalah pendapat dari Ibn Tamiyah dan muridnya Ibn al-Qayyima al-Jauriyah, yang menyatakan bahwa tidak ada perbedaan dalam nashantara jarimah hirabah dan selain birabah lebih pantas untuk hapus hukumannya. ${ }^{40}$ Adapun firman Allah SW'T Q.S An-Faal ayat 38:

"Katakanlah kepada orang-orang yang kafir itu: "Jika mereka berhenti (dari kekafirannya), niscaya Allah akan mengampuni mereka tentang dosa-dosa mereka yang sudah lalu; dan jika mereka kembali lagi .Sesunggubnya akan Berlaku (kepada mereka) sunnah (Allah terhadap) orang-orang dabulu”.

${ }^{40}$ Ahmad Dzajuli, Fiqih Jinayah ..., loc. Cit.h.231.
Para fuqaha sepakat pengampunan dalam jarimah ta'zir itu haruslah atas dasar tuntutan kemaslahatan, disamping itu juga ta'sir berkaitan dengan hak perorangan yang berhak memaafkan adalah oleh pihak korban, sedangkan yang berkaitan dengan hak Allah maka hanya hakim yang bisa memaafkan. Dan apabila jarimah yang berkaitan dengan hak campuran antara perorangan dan jamaah, maka bila korban telah memaafkan, maka tinggal satu hak Allah, maka hakim masih boleh menghukumnya.

Lebih jauh lagi tentang pemaafan al-Mawardi berpendapat sehubung dengan pemaafan, adalah sebagai berikut:

a. Bila pemaafan hak Adami diberikan sebelum pengajuan gugatan kepada hakim, maka Ulil Amri bisa memilih antara menjatuhkan sanksi ta'zir dan memaafkannya.

b. Bila pemaafan diberikan sesudah mengajukan gugatan kepada hakim oleh korban, maka ada perbedaan diantara fuqaha berkaitan hapusnya hak Ulil Amri dalam penjatuhan hukuman yang berkaitan dengan hak masyarakat. Ada yang berpendapat bahwa Ulil Amri itu menjadi hapus dengan pengajuan gugatan oleh korban. Pendapat ini dipegang oleh Abu Abdillah al-Zubair dan 
demikian pula pendapat Ahmad ibn Hanbal. Sedangkan menurut pendapat para ulama yang lain hak tersebut tetap saja tidak dapat dihapus, baik sebelum atau sesudah pengajuan gugatan yang berhubungan dengan jamaah. ${ }^{41}$

Tindak pidana korupsi merupakan sebuah jarimah, sebab korupsi tidak termasuk kedalam wilayah jarimah budud tidak pula masuk dalam cakupan jarimah qisas. Kedua macam jarimah ini secara jelas telah disebutkan dalam Al-Qur'an maupun hadis, bahkan jenis dan jumlah sanksinya juga telah dijelaskan oleh sumber utama ajaran agama Islam tersebut. Tindak pidana korupsi yang terjadi di Indonesia saat ini masuk dalam kategori jarimah ta'zir. Walaupun tindak pidana korupsi hanya masuk ke dalam jenis jarimah ta'zir, namun bahaya dan pengaruh negatifnya bisa lebih besar dari sekedar mencuri dan merampok. Maka, bentuk hukuman ta'zirnya dapat berupa pemecatan, hukuman kurungan, penjara seumur hidup bahkan bisa berupa hukuman mati.

Jarimah hudud dan jarimah ta'zir terdapat perbedaan jarimah budud yang yaitu hukuman yang ditentukan oleh syara' sedangkan jarimah ta'zir adalah jarimah yang hukumanya belum

${ }^{41}$ Ahmad Dzajuli, Fiqih Jinayah "Upaya Menanggulangi Kejahatan dalam Islam"..., Op. cit., h. 225-226. ditentukan oleh syara' dan diserahkan kepada pemerintah untuk menetapkannya. Dari pengertian ini jelaslah bahwa antara budud dan ta'sir terdapat perbedaan. Sayid Sabiq mengemukakan perbedaan tersebut sebagai berikut:

a) Hukuman budud diberlakukan secara sama untuk semua orang (pelaku), sedangkan hukuman ta'zir pelaksaannya dapat berbeda antara satu pelaku dengan pelaku lainnya, tergantung kepada perbedaan kondisi masingmasing pelaku. Apabila seseorang yang terhormat dan baik-baik, suatu ketika tergelincir melakukan tindak pidan ta'şir maka kondisinya itu dapat dijadikan pertimbangan untuk membebaskannya atau menjatuhkan hukuman yang lebih ringan. Sebaliknya, kepada orang yang perilakunya tidak baik melakukan jarimah ta'zir yang sama dapat dijatuhkan hukuman lebih berat.

b) Dalam jarimah hudud tidak berlaku pembelaan (syafa'at) dan pengampunan apabila perkaranya sudah dibawa ke pengadilan. Sedangkan untuk jarimah ta'żir, kemungkinan untuk memberikan pengampunan terbuka lebar, baik oleh individu maupun pemerintah.

\section{Prosedur Dalam Pemberian Remisi}


Prosedur pengajuan pemberian Remisi di Indonesia berdasarkan keputusan Presiden Republik Indonesia dalam pasal 4 Nomor 174 Tahun 1999 tetang Remisi manyatakan bahwa besarnya Remisi umum adalah :

\section{Remisi Umum}

a. 1 (satu) bulan bagi Narapidana dan Anak Pidana yang telah menjalani pidanaya selama 6 (enam) sampai 12 (dua belas) bulan

b. 1 (satu) bulan bagi Narapidana dan Anak pidana yang telah menjalani masa pidana selama 12 (dua belas) bulan atau lebih.

c. 3 (tiga) bulan bagi Narapidana dan Anak pidana yang menjakani masa pidananya pada tahun kedua.

d. 4 (empat) bulan bagi Narapidana dan Anak pidana yang menjalani masa pidananya pada tahun ketiga

e. 5 (lima) bulan bagi Narapidana dan Anak pidana yang menjalani masa pidananya pada tahun keempat dan tahun kelima.

f. 6 (enam) bulan bagi Narapidana dan Anak pidana yang menjalani masa pidananya pada tahun keenam dan selamanya.

Pemberian Remisi umum dilaksanakan sebagai :

a. Pada tahun pertama diberikan Remisi sebagaimana dimaksudkan dalam ayat (1) b. Pada tahun kedua diberikan Remisi tiga bulan

c. Pada tahun ketiga diberikan Remisi empat bulan

d. Pada tahun keempat dan kelima masing-masing diberikan remisi lima bulan, dan

e. Pada tahun keenam dan seterusnya diberikan Remisi enam bulan setiap tahun (Pasal 4 ayat 2)

Pemberian Remisi umum dilaksanakan pada Proklamasi Kemerdekaan Republik Indonesia tiaptiap tanggal 17 Agustus.

2. Remisi Khusus

Dalam pasal 5 Keputusan Presiden Republik Indonesia Nomor 174 Tahun 1999 tentang Remisi menyatakan bahwa besarnya Remisi khusus adalah.

a. 15 hari bagi Narapidana dan Anak pidana yang telah menjalani masa pidananya selama enam sampai 12 bulan.

b. Satu bulan bagi Narapidana dan Anak pidana yang telah menjalani masa pidananya selama 12 bulan atau lebih.

c. Pada tahun kedua dan ketiga masing-masing diberikan Remisi sebesar 1 bulan

d. Pada tahun keempat dan kelima, masing-masing diberikan Remisi sebesar 1 bulan 15 hari. 
e. Pada tahun keenam masingmasing diberikan Remisi sebesar dua bulan.

\section{Pemberian Remisi Khusus}

dilaksankan sebagai berikut :

a. Pada tahun pertama diberikan Remisi sebagaimana dimaksudkan dalam ayat (1).

b. Pada tahun kedua dan ketiga masing-masing diberikan Remisi satu bulan

c. Pada tahun keempat dan kelima masing-masing diberikan Remisi 1 bulan 15 hari dan

d. Pada tahun keenam dan seterusnya diberikan Remisi dua bulan setiap tahun (Pasal 5 ayat 2).

Pemberian Khusus dilaksanakan pada:

a) Setiap Hari Raya Idul Fitri bagi Narapidana dan Anak Pidana yang beragama Islam.

b) Setiap Hari Raya Natal bagi Narapidan dan Anak Pidana yang beragama Kristen.

c) Setiap Hari Raya Nyepi bagi narapidana dan Anak Pidana yang beragama Hindu.

d) Setiap Hari Raya Waisak bagi Narapidana dan Anak Pidana yang beragama Budha.

Apabila selama menjalani pidana narapidana atas anak pidana pindah agama, maka Remisi diberikan kepadanya menurut agama yang dianut pada saat dilakukan pendataan pertama kali.

\section{Remisi Tambahan}

Bedasarkan pada pasal 6 Keputusan Presiden Republik Indonesia Nomor 174 Tahun 1999 tentang Remisi, menyatakan bahwa besarnya Remisi tambahan adalah:

a. 1/2 (satu perdua) dari Remisi umum yang diperoleh pada tahun bersangkutan bagi narapidana dan anak pidana yang telah berbuat jasa bagi negara atau yang telah melakukan perbuatan yang bermanfaat bagi negara atau kemanusiaan.

b. 1/3 (satu pertiga) dari Remisi umum yang diperoleh pada tahun bersangkutan bagi narapidana dan anak pidana yang telah melakukan perbuatan yang membantu kegiatan pembinaan di Lembaga Pemasyarakatan sebagai pemuka.

Keputusan Menteri hukum dan Perundang-Undangan Republik

Indonesia Nomor M.09.HN.02.01 Tahun 1999 Tentang Pelaksanaan Keputusan Presiden Republik Indonesia 174 Tahun 1999 Tentang Remisi guna melaksanakan Keputusan Presiden Nomor 174 Tahun 1999 Tentang Remisi tersebut, khususnya dalam hal pemberian Remisi khusus kepada Narapidana dan Anak pidana, Menteri Hukum dan PerundangUndangan Republik Indonesia 
Mengeluarkan Keputusannya Nomor M.09.HN.02.01 Tanggal 23 Desember 1999, yang menegakkan bahwa:

a) Dalam hal pemberian Remisi, Menteri Hukum dapat mendelegasikan pelaksanaannya kepada Kepala Kantor Wilayah (pasal 2 ayat 1 ).

b) Perubahan pidana seumur hidup menjadi pidana sementara diusulkan kepada Menteri oleh Kepala Lembaga Pemasyarakatan melalui Kepala Kantor Wilayah.

c) Apabila selama menjalani masa pidananya Narapidana dan Anak pidana yang bersangkutan berpindah agama, maka pemberian Remisi khusus kepada Narapidana dan Anak pidana tersebut dilakukan bedasarkan agama yang dianut oleh yang bersangkutan pada saat pendataan pertama kali.

Keputusan Menteri Hukum dan Perundang-Undangan Republik Indonesia Nomor M.10.HN.02.01 Tahun 1999 Tentang Pehimpunan Wewenang Pemberian Remisi Khusus Pada Hari Natal 1999 dan pada Hari Raya Idul Fitri 1940 Hijriyah Tahun 2000 Surat Keputusan Menteri Hukum dan Perundang-Undangan Nomor M.10.HN.02.01 Tanggal 23 Desember 1999 dilakukan mengigat bahwa waktu pemberian Remisi bagi Narapidana dan Anak pidana yang beragama Kristen protestan dan Keristen Katolik tinggal hanya dua hari lagi yaitu pada tanggal
25 Desember1999 serta hari Raya Idul Fitri pada tahun berikutnya yang hanya berkisar dua minggu lagi. Pada tahuntahun berikutnya pelaksanaan Keputusan Presiden tersebut kembali sebagaimana biasanya.

$$
\text { Surat Edaran Direktorat }
$$
Jenderal Pemasyarakatan Nomor E.UM.01.10-130 Tahun 2001 Tentang Penjelasan Remisi Khusus yang Tertunda dan Remisi Khusus yang Bersyarat Serta Remisi Tambahan.

Dalam surat edaran ini dibahas tentang :

a) Remisi Khusus Tertunda

Penjelasan mengenai pembeian Remisi ini yaitu apabila Narapidana dan Anak Pidana yang bersangkutan telah memenuhi syarat subtantif pada saat hari besar agama.Pada saat tersebut yang bersangkutan masih berada dalam status sebagai seorang tahanan yang mengakibatkan dirinya tidak berhak menerima Remisi khususnya pada saat itu. Remisi khusus yang menjadi haknya tersebut akan diusulkan ketika statusnya sebagai seorang narapidana telah memperoleh kekuatan hukum yang tetap dan telah dieksekusi oleh Jaksa Penuntut Umum.

b) Remisi Khusus Bersyarat

Remisi khusus bersayarat diberikan kepada narapidana dan anak pidana pada saat hari besar agama yang dianutnya ketentuan diberi pengusulan Remisi khusus ini adalah apabila 
narapidana dan anak pidana yang akan diusulan tersebut belum genap enam bulan mennunjukan masa pidananya yang terhitung mulai tanggal pendataannya pada tingkat penyidik.

Berdasarkan uraian diatas, prosedur pemberian Remisi dalam hukum pidana di Indonesia terdapat perbedaan dengan hukum pidana Islam.Dalam hukum di Indonesia, prosedur pemberian Remisi atau pengurangan hukuman diberikan setelah putusan hakim atau sesudah dijatuhkan hukuman (vonis).Sedangkan dalam hukum pidana Islam, prosedur pengurangan hukuman dapat diberikan sebelum atau setalah putusan hakim. ${ }^{42}$

Pengurangan hukuman dalam hukum pidana Islam yang diberikan sebelum putusan hakim yakni pada jarimah budud dan jarimah qisas atau diyat. Sedangkan pada jarimah ta'zir dapat dilakukan sebelum atau sesudah putusan hakim.

\section{Syarat-Syarat dalam Pemberian Remisi}

Hukum pidana Islam pada umumnya menegakkan keadilan agar terciptanya ketertiban, ketentraman di masyarakat. Apabila masyarakat patuh terhadap hukum berarti mencintai keadilan. Karena kondisi masyarakat Indonesia yang majemuk sehingga

${ }^{42}$ Hafidzi, "Eksistensi Advokat Sebagai Profesi Terhormat (Officium Nobile) Dalam Sistem Negara Hukum Di Indonesia." perlu peraturan-peraturan hukum yang senatiasa untuk menciptakan suatu keadilan bagi seluruh masyarakat Indonesia.

Dalam pemberian Remisi di Indonesia, syarat-syaratnya harus memenuhi kriteria yag sesuai dengan Keputusan Presiden No. 174 Tahun 1999 Tentang Remisi, dalam pasal 1 ayat (1) aturan pokok, yaitu:

Setiap Narapidana dan Anak pidana yang menjalani pidana penjara sementara, ${ }^{43}$ dan pidana kurungan dapat diberikan Remisi apabila yang bersangkutan berkelakuan baik selama menjalani pidana.

Dan dalam pasal 3 dijelaskan juga:

Remisi Tambahan adalah pengurangan masa pidana yang diberikan kepada Narapidana dan Anak Pidana yang berbuat jasa kepada Negara, ${ }^{44}$ melakukan perbuatan yang bermanfaat bagi Negara atau kemanusiaan $^{45}$ atau melakukan

${ }^{43}$ Pidana sementara adalah bagi narapidana yang sudah menjalani pidananya lebih enam bulan. Lihat Keputusan Presiden Republik Indonesia nomor: 174 Tahun 1999 Tentang Remisi, Pasal 12.

${ }^{44}$ Yang dimaksud berbuat jasa kepada Negara adalah jasa yang diberikan dalam perjuangan untuk mempertahankan kelangsungan hidup Negara. Lihata Keputusan Menteri Hukum dan Perundang-undangan Nomor: M.09.HN02.01 Tentang Pelaksanaan Remisi Pasal 1 ayat (6)

${ }^{45}$ Perbuatan yang bermanfaat bagi Negara atau kemanusiaan antara lain : 


$\begin{aligned} & \text { perbuatan yang membantu } \\ & \text { kegiatan } \\ & \text { Pemasyarakatan. }\end{aligned}$
${ }^{46}$

Bagi narapidan yang bestatus hukumannya seumur hidup, maka syarat-syarat yang harus dipenuhi dan mendapatkan Remisi adalah dengan cara mengubah hukuman pidan seumur hidup menjadi pidana semntara. Dan hal tersebut sesuai dengan Keputusan Presiden Repunlik Indonesia Nomor: 174 Tahun 1999 tentang Remisi, yaitu dalam pasal 9 ayat (1-4) disebutkan bahwa:

1. Narapidana yang dikenakan pidana penjara seumur hidup dan telah menjalani pidana paling sedikit 5 (lima) beturut-turut serta berkelakuan baik, dapat diubah pidannya menjadi pidana sementara, dengan lama pidana yang harus dijalani paling lama 15 (lima belas) tahun.

- Menghasilakn karya dalam mengajukan Ilmu Pengetahuan dan teknologi yang berguna untuk pembanguan dan kemanusiaan.

- Ikut menanggulangi bencana alam.

- Mencegah pelarian dan gangguan keamanan serta ketertiban di Lembaga Permasyarakatan, Rumah Tahanan Negara atau Cabang Rumah Tahanan Negara.

- Menjadi donor darah organ tubuh dan sebagainya. Ibid, pasal 1 ayat (7)

${ }^{46}$ Yang dimaksud dengan perbuatan yang membantu kegiatan dinas Lembaga Permasyarakatan adalah pekerjaan yang dilakukan oleh seorang Narapidana yang diangkat sebagai Pemuka Kerja oleh Kepala Lembaga Permasyarakatan/Rumah Tahanan Negara/Cabang Rumah Tahanan Negara.
2. Perubahan pidana seumur hidup menjadi sementara sebagaimana dimaksud dalam ayat ditetapkan dengan Keputusan Presiden Republik Indonesia.

3. Permohonan perubahan pidana penjara seumur hidup menjadi pidana penjara sementara diajukan oleh narapidana yang bersangkutan kepada Presiden Republik Indonesia melalui Menteri Hukum dan Perudang-undangan.

4. Ketentuan melalui tata cara mengajukan permohanan perubahan pidana seumur hidup menjadi pidana sementara sebagaimana dimaksud dalam ayat (3) diatur lebih lanjut dengan Keputusan Menteri Hukum dan Perundang-Undang.

Sedangkan dalam ajaran Islam berkelakuan baik merupakan manifestasi dari sifat dan wujud penyempurnaan dari rasa penyesalan seseorang atas perbuatan masalalunya (perbuatan jahat telah ia lakukan) dan juga sebagai wujud dari penyempurnaan taubat seseorang. Sebagaimana dalam Al-Qur'an telah dijelaskan bahwa orang yang bertaubat dikatakan sempurna bila ia tidak hanya menyesali perbuatannya saja, tetapi ia harus mengikuti dan mengganti perbuatan tersebut dengan perbuatan baik. Sebagaiman firman Allah SWT pada Q.S Al-Furqan ayat 71:

"dan orang-orang yang bertaubat dan mengerjakan amal saleh, Maka 
Sesungguhnya Dia bertaubat kepada Allah dengan taubat yang sebenar-benarnya".

Terkait dengan pengurangan hukuman Remisi pelaksanannya dilakukan secara bertahap dan bertingkat oleh Lembaga Pemasyarakatan, hal ini untuk mengetahui sejauh mana Narapidana tesebut terbukti menunjukkan kesungguhan dalam bertaubat.

Menurut pendapat lain dalam Hasyiyah Ibn Abidin, menurut para ulama bila ia memperlihatkan tandatanda perbaikan perilakunya, karena taubatnya dalam hati itu, tidak dapat diamati. ${ }^{47}$ Tuhan sebagai otoritas yang tertinggi, akan memberikan hukuman kepada manusia yang bersalah dan akan menggugurkan hukuman bagi manusia yang mau bertaubat dan menyesali perbuatan yang pernah ia lakukan selama ini dengan bersungguhsungguh, hal ini adalah merupakan syari'at dan ketentuan dari Allah, dan karenanya tidak ada lagi hukuman bagi manusia yang bertaubat. Sebagaimana yang telah dikutip oleh Mamud Syaltut. $^{48}$

Bahwasannya Allah akan memberikan taufiq dan hidayah, sehingga dari saat ke saat niat tekadnya untuk mendekatkan diri kepada Allah

${ }^{47}$ Ahmad Djazuli, Fiqh Jinayah "Upaya Menanggulangi Kejahatan dalam Islam" (Jakarta: Raja Grafindo Persada, 1997), h. 204.

${ }^{48}$ Mahmud Syaltut, Akidah dan Syariat Islam II, alih bahasa Facruddin HS (Jakarta: Bina Aksara, 1985), h. 29-30. semakin kukuh dan amalnya akan semakin baik dan bertambah. Setiap kita melakukan tindakan, entah tindakan terhadap diri kita ataupun terhadap diri orang lain sebaiknya kita pikirkan terlebih dahulu atas kemanfaatan dan kemudaratan dari perbuataan tersebut. Apabila kita benar bersungguh-sungguh dalam bertaubat maka sepantasannya kita akan mendapatkan pengampunan berupa pengurangan dan potongan menjalani pidana Remisi, karena sudah menjadi khodrat manusia bahwa manusia tidak luput dari perbuatan dosa dan aniaya, serta hanya dengan taubat dan menggantikannya dengan perbuatan baik itulah yang akan termasuk insan yang beruntung dan taubantnya diterima disisi Allah SWT. sebagaimana firman Allah SWT pada Q.S An-Nissa 16:

"dan terhadap dua orang yang melakukan perbuatan keji di antara kamu, Maka berilah bukuman kepada keduanya, kemudian jika keduanya bertaubat dan memperbaiki diri, Maka biarkanlah mereka. Sesunggubnya Allab Maha Penerima taubat lagi Maha Penyayang”.

Adapun pemberian Remisi di Indonesia dilaksanakan dengan dua cara yaitu:

1. Dilaksanakan

secara bertahap, ini diharapakan agar proses pembinaan dan pemahaman pembinaan betul-betul telah tertanam 
dalam jiwa Narapidana, sehingga akan mampu mewujudkan tindakan yang dilandasi dengan moral dan hati nurani serta jiwa yang mantap. Pemahaman akan pembinaan yang tertanam dalam jiwa setiap Narapidana akan mampu meredam untuk bertindak pidana lagi kelak bilamana kembali ke tengah-tengah masyarakat. Karena pengalamanpengalaman yang telah dirasakan pada waktu menjalani pidana cukup dapat dijadikan pelajaran yang berharga. Sehingga pemberian Remisi secara bertahap ini diharapkan sebgai upaya untuk mencapai sasaran tersebut, yaitu terwujudnya tindakan lahir dari Narapidana yang terwujud perilaku baik yang dilandasi moral dan nurani serta jiwa yang tenagng dan kokoh.

2. Sedangkan pemberian Remisi secara bertingkat, hal ini dimaksudkan untuk menunjukkan bahwa keistiqomahan dalam menaati peraturan yang ditetapkan oleh pemerintah melalui Lembaga Permasyarakatn semakin baik. Di samping itu narapidana yang lebih lama menjalani pembinaan diharapkan akan lebih baik kesadarannya dibandingkan dengan Narapidana yang baru menjalani pemidanaan.

Dalam hal hukuman sebagai media pendidikan dan pembinaan, maka hal tersebut dapat dilihat dari pelakasanaan Remisi di Indonesia yang diberikan kepada narapidana setelah narapidana tersebut menjalani pidananya dalam kurun waktu tertentu.Jadi pengurangan di sini semata-mata bukanlah pengurangan biasa tanpa adanya kriteria tertentu untuk mendapatkan hak tersebut. Tetapi konsekuensi yang harus diterima oleh narapidana yang ingin mendapatkan Remisi harus menjalani hukuman dalam kurun waktu lebih dari enam bulan ( 6 bulan) dan disamping itu narapidana yang bersangkutan harus menunjukan perilaku yang baik selama menjalani pemidanaan.

Dari keterangan di atas, tampak bahwa syarat atau kriteria pokok dari pemberian pengurangan masa hukuman (Remisi) di Indonesia (dalam hukuman pidana positif) pada dasarnya tidak terlepas dari prinsip-prinsip pokok dalam Islam.hal ini dapat kita cermati bahwa kriteria atau syarat yang harus dipenuhi oleh pelaku, yakni dengan berbuat baik selama di tahanan, 
menyesalinya dan berniat untuk tidak mengulangi. ${ }^{49}$

\section{Kesimpulan}

Dari pembahasan yang telah penulis kemukakan di atas mengenai Remisi di Indonesia dalam pandangan hukum pidan Islam, maka sampailah penulis pada bagian kesimpulan skripsi ini.Kesimpulan dapat dikemukakan sebagai berikut.

1. Pelaksanaan remisi di Indonesia menurut Keputusan Presiden Republik Indonesia Nomor: 174 Tahun 1999 Tentang Remisi, pada dasarnya tidak terlepas dari prinsip-prinsip pokok hukum pidana Islam. Akan tetapi hal ini terdapat sedikit perbedaan yakni dalam hukum pidana Islam pengurangan hukuman dapat diberikan sebelum atau sesudah keputusan hakim (vonis). Remisi khusus masa pengurangan pidana yang diberikan kepada narapidana dan anak pidana pada Hari Besar Keagamaan yang dianut oleh bersangkutan, Remisi Tambahan adalah pengurangan masa pidana kepada narapidana dan anak pidana yang berbuat

\footnotetext{
${ }^{49}$ Menghasilakn karya dalam mengajukan Ilmu Pengetahuan dan teknologi yang berguna untuk pembanguan dan kemanusiaan.Ikut menanggulangi bencana alam.Mencegah pelarian dan gangguan keamanan serta ketertiban di Lembaga Permasyarakatan, Rumah Tahanan Negara atau Cabang Rumah Tahanan Negara.Menjadi donor darah organ tubuh dan sebagainya.Ibid, pasal 1 ayat (7)
}

jasa kepada Negara, dan membantu kegiatana Lembaga Pemasyarakatan lainnya. Setiap narapidana dan anak pidana berhak mendapatkan Remisi, adapun jenis Remisi yaitu, Remisi umum yang diberikan pada Hari Peringatan Proklamasi Kemerdekaan RI tanggal 17 Agustus, Tujuan pemberian Remisi di Indonesia merupakan sebagai motivator atau stimulasi untuk berkelakuan baik, untuk mengurangi dampak negatif dari hukuman yang dijatuhkan.

2. Konsep hukum pidana Islam berpangkal pada kemaslahatan untuk pencegahan (ar-radu wazzajru) pendidikan dan pengajaran (al-Islah al-Tahzib). Tujuan ini bertujuan untuk mencegah pelaku tindak pidana agar tidak mengulangi lagi perbuatannya, dan juga berfungsi untuk mencegah orang lain agar tidak melakukan tindak pidana serupa. Tindak pidana korupsi merupakan sebuah jarimah, sebab korupsi tidak termasuk kedalam wilayah jarimah budud tidak pula masuk dalam cakupan jarimah qisas. Melainkan termasuk dalam wilayah jarimah ta'zir. Walaupun tindak pidana korupsi hanya masuk ke dalam jenis jarimah ta'zir, namun bahaya dan pengaruh negatifnya bisa lebih besar dari sekedar mencuri dan merampok. Maka, bentuk 
hukuman ta'zir dapat berupa pemecatan, hukuman kurungan, penjara seumur hidup bahkan bisa berupa hukuman mati. Maka dalam jarimah budud tidak berlaku pengampunan (syafa'at) apabila perkaranya sudah dibawa ke pengadilan. Sedangkan untuk jarimah ta'zir, kemungkinan untuk memberikan pengampunan (syafa'at) terbuka lebar, baik oleh individu maupun pemerintah.

\section{Saran-saran}

Sebagai akhir dari peyusunan skripsi ini, penulis perlu menyampaikan beberapa saran yaitu:

1. Dalam pemberian Remisi kepada Narapidan koruptor, perlu adanya perubahan peraturan tentang aturan Nomor 174 Tahun 1999 Tentang Remisi dan bagi korupsi harus disendirikan sendiri, harus ada tingkatantingkatan dalam memberikan sebuah Remisi, mengingat korupsi di Indonesia semkain merajalela dan merugikan Negara.

2. Harus diadakan peraturan yang jelas oleh pemerintah untuk dimasa akan datang, untuk mengatur masalah pemberian Remisi terhadap tindak pidana koruptor baik dengan cara mengahapus Remisi maupun melakukan vertifikasi terhadap pemberian Remisi terhadap koruptor karena dinilai belum jelasnya peraturan yang ada sekarang.

\section{Daftar Pustaka}

Armanndo. Nina M., et al. Enksiklopedi Islam (Jakarta: Ichtiar Baru Van Hoeve, 2005).

Anwary "Perang Melawan Korupsi Di Indonesia" (Bogor, 2012).

Al-Munawwir, A.Warson Munawwir, Kamus Arab-Indonesia (Yogyakarta: Unit Pengadaan buku-buku Ilmiah Keagamaan Ponpes al_Munawwir, 1984).

Abu Daud, Sunan Abi Daud, Kitab Hudud, Bab Afwi an alHududi Malam Tablughi as-Sultana (Beirut : Mua'sasah Rayyan, 1998 $\mathrm{M} / 1319 \mathrm{H}) \mathrm{V} \quad$ : 72-73, Hadits Nomor 4376. Hadits dari Abdullah bin Amr bin Ash.

Ash Shiddieqy. M.Hasbi, Falsafah Hukum Islam (Jakarta: Bulan Bintang, 1990).

Abdul Azis Dahlan, et.al., (eds), Eksiklopedi Hukum Islam (Jakarta: Icthiar Baru Van Hoeve, 1996). Jilid 5

Ahmad Dzajuli, Fiqih Jinayah "Upaya Menanggulangi Kejahatan dalam Islam”. (Jakarta: Raja Grafindo persada, 1997)

Ahmad Hanafi, Asas-Asas Hukum Pidana Islam (Jakarta: Bulan Bintang, 1967).

Ahmad Wardi Muslich, Hukum Pidana Islam (Jakarta: Sinar Grafika, 2005). 
Dzajuli. Ahmad, Fiqih Jinayah "Upaya Menanggulangi Kejabatan dalam Islam”. (Jakarta: Raja Grafindo persada, 1997.

Djazuli. Ahmad, Fiqh Jinayah 'Upaya Menanggulangi Kejahatan dalam Islam” (Jakarta: Raja Grafindo Persada, 1997), h. 204.

Hafidzi, Anwar. "Eksistensi Advokat Sebagai Profesi Terhormat (Officium Nobile) Dalam Sistem Negara Hukum Di Indonesia." Khazanab: Jurnal Studi Islam Dan Humaniora 13, no. 1 (2015).

Ibnu Majah, Sunan ibnu Majah, Bab alAfwi bi al-Qishasha, (Beirut: Dar al-Fakr, $\mathrm{t}, \mathrm{t}$ )

Imam abu Zakariya Yahya bin Syaraf An- Nawawi, Riadbus Shalibin Min Kalaami Syaidil Mursalyin ( Damaskus: Darul Khair, $1420 \mathrm{H})$.

Syekh Mahmud Syaltut, "Aqidah dan Syari'ah Islam II", alih bahasa facruddin Hs(Jakarta: PT. Bima Aksara, 1985).

Makhrus Munajat, Hukum Pidana Islam di Indonesia (Yogyakarta: Teras, 2009).

Muhammad Bin Alwi Al Maliki, keutamaan Umat Muhammad, alih bahasa Bughawi (Jakarta: Bintang Terang, 2001)

Muslich. Ahmad Wardi, Hukum Pidana Islam, ( Jakarta: Sinar Grafika, 2005)

M. Nurul Irfan "Korupsi dalam Hukum Pidana Islam" (Jakarta: Pena Grafika,2012)
Zainal Arifin"Tinjauan Hukum Islam Terbadap Pemberian Remisi Pada Narapidana". Skripsi 